\title{
article JOURNALISM AND FACT-CHECKING: \\ typification of sources used for checking and criteria for selecting fact-checked material - an analysis by Agência Lupa and Aos Fatos
}

DANIEL DE REZENDE DAMASCENO

Universidade Federal da Bahia, Salvador - Bahia - Brazil

ORCID: 0000-0003-2191-5616

EDGARD PATRÍCIO

Universidade Federal do Ceará, Fortaleza - Ceará - Brazil

ORCID: 0000-0002-3130-8628

DOI: 10.25200/BJR.v16n2.2020.1212

Received in: March 3 ${ }^{\text {rd }}, 2019$

Desk Reviewed: May $12^{\text {th }}, 2019$

Desk Review Editor: Claudia Lago

Revised on: September $9^{\text {th }}, 2019$

Revised on: December $12^{\text {th }}, 2019$

Revised on: April 16 th, 2020

Approved on: April 28 $8^{\text {th }}, 2020$

\begin{abstract}
Fact-checking was initially used to verify the factuality of information given by political agents. However, the proliferation of false information on social networks and concerns about the political use of spreading lies have led to fact-checking methodologies also being used to combat fake news. In terms of a cognitive and behavioral approach, Lazer et al. (2018) suggest there are some doubts as to how effective this methodology is. This article analyzes the performance of two Brazilian checking agencies, Aos Fatos and Agência Lupa. We demonstrate that, although checking discourse is directly related to the credibility of organizations, the agencies themselves do not lay out the criteria for selecting what is to be checked. The platforms that use this form of fact-checking mainly rely on data and studies provided by official sources and public institutions, once again compromising the credibility of the process
\end{abstract}

Key words: Journalism. Fact-checking. Internet. Fake news. 


\section{JORNALISMO E FACT-CHECKING: \\ tipificação das fontes da base da checagem e critérios na seleção do material checado - uma análise da Agência Lupa e Aos Fatos}

RESUMO - A prática de fact-checking foi iniciada para verificar a factualidade das informações nos discursos de agentes políticos. Mas a proliferação de informações falsas nas redes sociais da internet, e a preocupação com a disseminação de mentiras como instrumento político, fez com que as metodologias de fact-checking também fossem utilizadas para combater fake news. Levando em consideração uma abordagem cognitiva e comportamental, Lazer et al. (2018) alertam que existem dúvidas quanto à eficácia dessa utilização. Esse artigo analisa a atuação de duas agências brasileiras de checagem, Aos Fatos e Agência Lupa. Demonstramos que, apesar da checagem de discursos ter relação direta com a credibilidade das organizações, as próprias agências não explicitam os critérios que orientam a seleção do que é checado. E que nessa modalidade de checagem, as plataformas de fact-checking se valem, sobretudo, de dados e estudos fornecidos por fontes oficiais e instituições públicas, comprometendo mais uma vez a credibilidade do processo.

Palavras-chave: Jornalismo. Fact-checking. Internet. Fake news.

\section{PERIODISMO Y FACT-CHECKING: tipificación de las fuentes de la base de verificación y criterios en la selección del material verificado - un análisis de Agência Lupa e Aos Fatos}

RESUMEN - La práctica de fact-checking inició para verificar la factualidad de las informaciones en los discursos de agentes políticos. Pero la proliferación de informaciones falsas en las redes sociales de internet, y la preocupación por la diseminación de mentiras como instrumento político, hizo que las metodologías de fact-checking también fueran utilizadas para combatir las fake news. Teniendo en cuenta un enfoque cognitivo y conductual, Lazer et al. (2018) advierten que existen dudas sobre la eficacia de esta utilización. Este artículo analiza la actuación de dos agencias brasileñas de chequeo, Aos Fatos y Agência Lupa. Demostramos que, aunque la verificación del discurso tiene una relación directa con la credibilidad de las organizaciones, las agencias mismas no detallan los criterios que guían la selección de lo que se verifica. Y que en este modo de verificación, las plataformas de verificación de hechos se basan principalmente en datos y estudios proporcionados por fuentes oficiales e instituciones públicas, comprometiendo una vez más la credibilidad del proceso.

Palabras clave: Periodismo. Fact-checking. Internet. Fake news.

\section{Introduction}

The number of journalistic vehicles dedicated to checking the veracity of information and public statements, a practice known as fact-checking, has increased throughout global media (Graves, 2016; Diniz, 2018). Unlike the conventional verification process, which requires checking information before it is published, fact-checking is dedicated to post-hoc checking, or in other words, verifying after statements and alleged facts after they have been published. Amazeen (2015) states: "As a form of accountability journalism, dedicated fact- 
checking is committed to publicizing errors of falsehoods regardless of the source" (p.3).

Although not a recent practice, fact-checking organizations and initiatives have gained greater visibility over the last decade (Uscinsky \& Butler, 2013; Amazeen, 2015; Dourado, 2016; Graves, 2016; Diniz, 2018). As Uscinsky and Butler (2013) point out, during the 2012 U.S. election campaign, fact-checking platforms had an unprecedented importance in the journalistic and political agenda:

During the 2012 election cycle, fact checking became a prominent facet of campaign news coverage. For example, the Tampa Bay Times fact checking arm, PolitiFact, assessed more than 800 statements related to the 2012 presidential campaign alone. The injection of fact checking into political coverage has largely been welcomed by news outlets and news audiences; fact-checking outlets are frequently cited by others journalists and by politicians whose opponents have been accused by the fact checkers of mendacity. (Uscinsky \& Butler, 2013. p.162).

More recent events have also highlighted the practice. In the first half of 2018, Facebook announced a verification project in partnership with signatory vehicles from the International FactChecking Network (IFCN)' ${ }^{1}$. This collaboration between Facebook and the IFCN came about after the crisis was worsened by investigations of fake news being used during the 2016 U.S. election campaign and the Facebook-Cambridge Analytica scandal².

As Diniz (2018, p.27) points out, after discussions on the use of fake news in the 2016 U.S. presidential election, "the practice of fact-checking [...] was thus considered an essential tool for verifying public speeches, it is a strategy used to combat fake news and prevent the spread of false information". Using fact-checking to combat the spread of misleading and false content has also flourished in Brazilian media. The following four Brazilian fact-checking initiatives are signatories to the IFCN: Aos Fatos, Agência Lupa, O Truco and Estadão Verifica. Aos Fatos and Lupa also participate in the Facebook verification project.

It is important to point out that, over the last few decades, journalism has undergone transformations within and outside of the newsroom. Charron and De Bonville (2016) comment on the transition from information journalism to communication journalism. Anderson et al. (2013) highlight the dismantling of journalism based on the industrial model and new productive routines. Fact-checking journalism has grown with this reshaping process. 
Graves (2016) points out that, in the United States, factchecking journalism is dominated by professionals who view their work as a new way of reporting. Fact checkers consider themselves to be participants in a reform movement and claim to reject he said, she said journalism and electoral coverage as horse racing ${ }^{3}$ (Graves, 2016). A similar analysis conducted in Brazil revealed that the media vehicle Aos Fatos considers fact-checking to be an essential part of journalistic work that, in recent years, has been neglected by newsrooms.

\begin{abstract}
As of the 2000s, the dynamism of the Internet has meant that some essential stages of the journalistic method have become unappreciated or overlooked. Whether due to the advent of real-time coverage or the loss of jobs in traditional newsrooms, ante hoc fact checking (that is, fact-checking performed before publication) became a secondary stage of the investigation, and reserved only to major reporting efforts. [...] This had led to the popularization of fact-checking ${ }^{4}$. (Aos Fatos, 2018a).
\end{abstract}

This scenario raises a few questions: 1) What is the nature of the speeches analyzed by checking agencies? 2) Where do these speeches come from? 3) What sources do the agencies use for evaluating these discourses? 4) What are the potential impacts of the checking process within the scope of journalism production? In order to try and answer these questions we analyzed the news coverage from two Brazilian fact-checking agencies: Aos Fatos and Agência Lupa. We chose these two initiatives based on the fact that they had both signed an agreement with Facebook, which meant both agencies were able to perform wider fact-checks, helping to expand the scope of our analysis. These two agencies also follow the IFCN code of conduct, which presupposes a potential uniformity of the data collected for analysis. The analysis corpus consists of checking reports published in January 2019. We chose this month and this year because it marked a change to several elective positions in Brazil. Thus, for reports where discourse was checked, we were able to compare the target relationship and checker relationship with the news. 113 checks from the two agencies were cataloged for analysis during this period.

In addition to these two agencies, the Truco and Estadão Verifica projects also participated in the IFCN. We excluded Truco from this analysis as it is no longer a permanent project ${ }^{5}$. The Estadão Verifica project, a fact-checking department of the Grupo Estado, was not included in our analysis because it became a signatory to the IFCN on January 16, 2019. In other words, this agency only started 
following the same code of conduct as the other agencies from the second half of our analysis period, which would have only given us partial results and an inaccurate analysis.

Despite the growing concerns surrounding fake news, we are not interested in providing a conceptual definition of the term. There is still a lot of discussion about what constitutes fake news. Lazer et al. (2018, p.1094) argue that fake news is "fabricated information that mimics news media content in form, but not in organizational process or internet". We believe this definition to be problematic as it seems to suggest that conventional media's organization of information or investigation processes are capable of preventing fake news. Allcott and Gentzkow (2017, p.213) define fake news as "news articles that are intentionally and veritably false, and could mislead readers". This second definition is more comprehensive than the first, however, it too is also problematic since it encompasses satirical and humor sites which may be erroneously considered factual.

It is important to point out that not all journalists who work for fact-checking agencies agree with the term fake news. Claire Wardle, from the First Draft agency, believes the term to be contradictory since, the way she sees it, if information is considered news, then it cannot be false. She also argues that the term does not encompass all forms of lies and errors in journalism, such as a recent photo which may be published with old captions (Resende, 2017).

The number of studies on fact-checking in Brazil has increased (Neisser, 2015; Dourado, 2016; Diniz, 2018) However, we observed a low number of studies focusing on the methods these fact-checking agencies use and how effective they are at combating disinformation.

Due to the inceptive and unstable nature of studies and research on fake news, including the lack of a consolidated definition of the concept in the field, we opted for an exploratory type of research for our study. Gil (1999) considers the main objective of exploratory research to develop, clarify and modify concepts and ideas in order to formulate more precise problems or more searchable hypotheses for further studying. As for the object of study, this study emulates a multiple case study, delimited by a nonprobabilistic sample, given the researchers' inference in defining its corpus. Yin (2001, p.28) defines a case study as a research strategy that has a specific advantage because "a question such as 'how' or 'why' is asked about a contemporary set of events over which the researcher has little or no control". 


\section{Fact-checking - values and history}

Traquina (2004) points out that journalistic work, in the context of a democratic society, involves a professional belief in certain values, including freedom, objectivity, and the search for professional autonomy and credibility. Thus, journalism must strive to "equip citizens with the vital tools to exercise their rights and give them a voice to express their concerns" (p.129).

Fact-checking journalism, despite having its own logic and characteristics, upholds these classic values related to the ideology of journalism, especially objectivity and credibility when searching for the truth. One factor supporting this interpretation can be seen in the history of journalism itself. American journalists, specialized in checking, trace the roots of this 'reform movement' back to the ad watch ${ }^{6}$, a term used for advertising surveillance initiatives that emerged in the country in the 1990s (Dobbs, 2012; Graves, 2013, 2016).

David Broder, a former columnist for the Washington Post, is often credited with shaping the style of coverage used for ad watches, encouraging colleagues to be more watchful of political advertising messages (Graves, 2013). After the widely criticized nature of the 1988 U.S. presidential campaign, "David Broder wrote a series of columns on the disaster, calling for reporters to start 'truth-squadding' campaign ads" (Graves, 2013, p.130).

Following the ad watch line, American journalist Brooks Jackson, a reporter for CNN in 1991, was tasked with checking the information that candidates for the presidency of the United States would give in television advertisements. Later, "Jackson founded AdPolice; the first team specialized in investigating election advertisements. In 2003, spurred on by the success of his work at CNN, Jackson launched the first independent factchecking website" (Lupa, 2015a) .

This made us realize that fact-checking started with a clear objective: to investigate the veracity of information in politicians' speeches. However, the spread of false information across social networks, and the growing concern about the use and dissemination of lies as a political instrument, has led factchecking agencies to also combat so-called fake news.

The IFCN has established a basic code of principles for its signatories, in order that their idea of journalism as an 
instrument for helping the public exercise their citizenship is realized. There are five basic codes of principles: (1) commitment to non-partisanship and honesty; (2) commitment to transparency of sources; (3) commitment to transparency regarding the entity's financing and organization; (4) commitment to transparency of methodology; and (5) commitment to making open and honest corrections (Poynter, 2016). In a similar vein, Amazeen (2015) considers autonomy and impartiality fundamental values for factchecking agencies, and an essential component for differentiating themselves from party vehicles.

\begin{abstract}
Although party bloggers can offer valuable scrutiny at times, they generally lack credibility among broader audiences because their work is limited to the opposition (Graves, Glaysier, 2012). As noted by former Washington Post fact-checker Michael Dobbs $(2012,13)$, when both sides are not criticized, 'you are no longer a checker, you are a tool in a political campaign'. (Amazeen, 2015, p.3).
\end{abstract}

However, even with these safeguarding systems, factchecking is not immune to criticism. Lazer et al. (2018) point out that fact-checking can even be used as a tool to help individuals evaluate the information they find on the Internet. However, in terms of a cognitive and behavioral approach, the authors warn that there are doubts about how effective it is in combating fake news. Generally speaking, individuals tend to not question the veracity of information unless it is in direct conflict with their moral views.

\begin{abstract}
Research also further demonstrates that people prefer information that confirms their preexisting attitudes (selective exposure), view information consistent with their pre-existing beliefs as more persuasive than dissonant information (confirmation bias), and are inclined to accept information that pleases them (desirability bias). Prior partisan and ideological beliefs might prevent acceptance of fact checking of a given fake news story. (Lazer et al., 2018, p. 1095).
\end{abstract}

Other criticisms made against fact-checking relate to its investigating and verification processes. In an analysis conducted by Uscinsky and Butler (2013), they deemed the methods used by checkers to assess the veracity of the information too simple since they treat facts as self-evident and do not consider them in a larger context.

The main criticism presented by these researchers concerns how checkers select which statements will be used. As the authors point out, politicians, activists and interest groups constantly make supposedly factual statements. However, journalists only need to select a few statements for checking, and usually do not have 
to inform the criteria for that selection. Thus, Uscinski and Butler (2013) consider that the criteria for newsworthiness in journalism might very well mesh with the demands of media companies, but it is not a rigorous and scientific selection method. "Without systematic statement selection, fact checkers may inadvertently (or deliberately) cherry pick and consequently, construct inaccurate images of political actors" (Uscinski \& Butler, 2013, pp. 165-166).

In response to these criticisms, Amazeen points out that despite the methodological limitations of fact-checking vehicles, the combination of different methods of analysis through a 'triangulation of checking' can compensate for individual weaknesses (Amazeen, 2015). In line with Amazeen's claims, Neisser (2015) further states:

\begin{abstract}
Amazeen analyzed 491 electoral advertising pieces that aired between 2008 and 2012. The results are extremely encouraging. All advertising evaluated by the agencies pointed to a $100 \%$ match, meaning all three had the same results. When only two agencies performed the evaluation, the match was no less than 95\%. As Amazeen concludes, 'fact-checkers who overwhelmingly reach similar conclusions using different methods lend credibility to their efforts, similar to that of a scientific triangulation'. (Neisser, 2015, p.201).
\end{abstract}

For Neisser (2015) and Amazeen (2015), the stability of checks and verifications helps to increase the reputation of fact-checking organizations. In fact, fact-checking organizations are spreading more and more in the media and gaining more relevance in Brazil.

Similarly to what goes on internationally, the Brazilian digital ecosystem has seen non-profit journalistic organizations grow over the last five years, organizations which are focused on retrieving information in the public interest. (Diniz, 2018, p.30).

As information and technological changes were taking place, new journalistic fact-checking projects were emerging and, included in this institutionalization of the practice, the IFCN was launched. Four Brazilian agencies are signatories to the fact-checking network: Aos Fatos, Agência Lupa, O Truco and Estadão Verifica. We shall discuss the modes of organization and methodology of two of these Brazilian agencies below: Aos Fatos and Agência Lupa, both objects of our analysis. 


\subsection{Aos Fatos - organization and methodology}

Aos Fatos is an online verification vehicle founded on July 7, 2015. The Aos Fatos site does not have any advertisements of any kind. It uses a hybrid model in order to finance itself: an annual crowdfunding campaign and fact-checking consultancies which are carried out through Aos Fatos Lab. Aos Fatos Lab is a technology and consultancy branch aimed at companies and civil society organizations with no political party affiliations. Aos Fatos Lab develops artificial intelligence and automated fact-checking projects. Among these projects is the artificial intelligence known as Fátima, developed as a messenger chat-bot ${ }^{8}$ to measure information available on the internet.

The Aos Fatos team is composed of journalists in Rio de Janeiro and São Paulo, and is also part of a national network of freelancers. The vehicle states that both staff and freelancers "share the same obsession: to seek the truth in politics" (Aos Fatos, 2018).

Aos Fatos checks each piece of information and then gives it a specific label: true, inaccurate, exaggerated, false, contradictory or indefensible.

Figure 1 - Truth Label - Aos Fatos

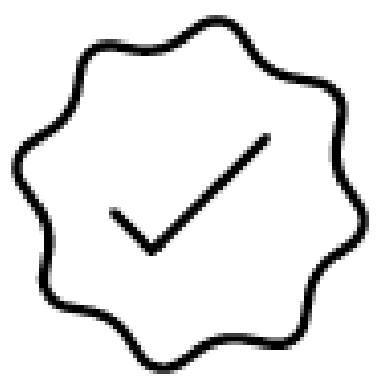

Source: Aos Fatos (2018b)

"Applying the TRUE label means: the statement is consistent with the facts and does not need to be contextualized" (Aos Fatos, $2018 b)$. 
Figure 2 - Inaccurate Label - Aos Fatos

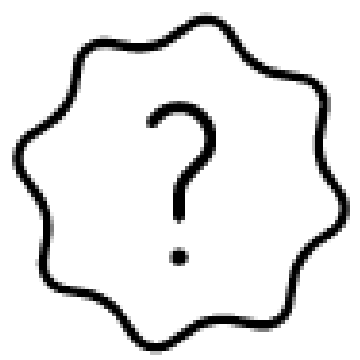

Source: Aos Fatos (2018b)

"When a statement is labelled INACCURATE, it means that the context needs to be verified. In other words, a particular statement in question may not be applicable" (Aos Fatos, 2018).

Figure 3 - Exaggerated Label - Aos Fatos

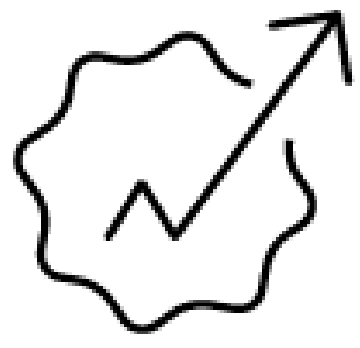

Source: Aos Fatos (2018b)

"The EXACGERATED label is applied to statements which are not entirely false, but are mostly false. They are also applied to statements which lack the data needed to prove their veracity" (Aos Fatos, 2018b).

Figure 4 - False Label - Aos Fatos

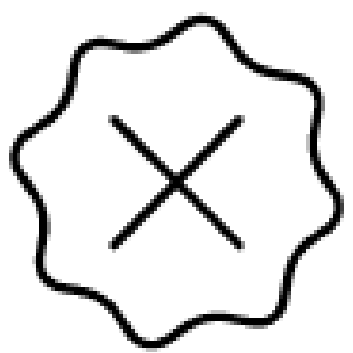

Source: Aos Fatos (2018b) 
"If a piece of information is untrue, it is labelled FALSE. It is that simple. The available data need only objectively contradict the information" (Aos Fatos, $2018 \mathrm{~b}$ ).

Figure 5 - Indefensible Label - Aos Fatos

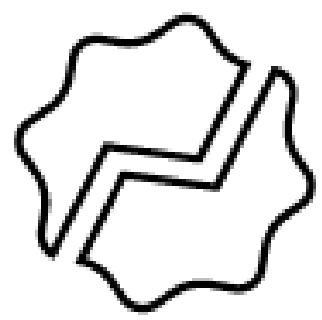

Source: Aos Fatos (2018b)

"The INDEFENSIBLE label applies to statements whose premises cannot be refuted or confirmed. In other words, it is applied when there are no facts to support the statement" (Aos Fatos, 2018b).

Figure 6 - Contradictory Label - Aos Fatos

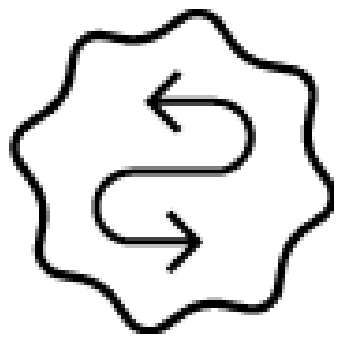

Source: Aos Fatos (2018b)

"The CONTRADICTORY label is used for a statement which is objectively in contrast to previous statements or actions attributed to the same person or institution that it represents" (Aos Fatos, $2018 \mathrm{~b})$.

Lastly, Aos Fatos states that what makes fact-checking so important is its concern for transparency. Aos Fatos admits that verification methods may vary slightly between the verification agencies, but they need to explain how they reached their conclusions about the veracity of the information published. 


\title{
2.2 Agência Lupa - organization and methodology
}

Agência Lupa was founded in November 2015. The Lupa website is hosted on the portal for Piauí magazine, which in turn, belongs to Universo Online (UOL) of the Grupo Folha. According to Agência Lupa, "journalists were born to be skeptical and to question. And the ones at Lupa do this incessantly, adhering to the methodology of their work" (Lupa, 2015b).

According to the Lupa agency, the innovative nature of fact-checking is how it applies journalistic techniques of verification and selection to the media. Lupa acts as a guardian and filter of factuality. The agency claims that before the Internet "people received information which was already filtered by members of the media, working as guardians and news holders. Now, people are bombarded with information [...] Lupa is your filter" (Lupa, $2015 \mathrm{a}$ ).

Lupa's financing or organization is no different from conventional journalistic media. Its business model is based on those of traditional news agencies such as Reuters, Associated Press and Bloomberg. Lupa performs fact-checking and then sells it in its articles to be published by other vehicles.

The verification methodology which Agência Lupa uses is based on a procedure influenced by other fact-checking platforms such as Chequeado from Argentina and PolitiFact from the U.S.

\begin{abstract}
Lupa is concerned with "who is speaking", "what is said", and "what kind of effect it has". It does not check opinions. It does not make predictions about the future. It does not highlight trends. It does not evaluate broad concepts. It strives to verify the degree of veracity of sentences that contain historical and statistical data, and comparisons and information related to the legality/constitutionality of a single fact. (Lupa, 2015).
\end{abstract}

Lupa also uses labels to specify the degrees of truth found in the statements. They are: 
Figure 7 - Labels - Agência Lupa

TRUE
The information is proven to be correct
TRUE, BUT...
The information is correct, but needs to be
explained further
TOO EARLY TO SAY
The information could be true. It has not yet
proven to be
EXAGGERATED

The information is almost correct, but there are some exagerrations

CONTRADICTORY

The information is in contrast to previous

information already released by the same source

\section{UNDERRATED}

The data is more serious than the information

\section{INDEFENSIBLE}

There is no public data to prove the information to be true

\section{FALSE}

The information is proven to be false

\section{UNDER REVIEW}

Label given for information being reviewed

Source: Agência Lupa (Lupa, 2015b).

Even though it believes in its methods, Agência Lupa admits that there are a few risks associated with fact-checking:

When immediacy and the search for a scoop are the focal points, the checker tends to publish more superficial information. You can label a sentence as being true or false without taking into account the broader scenario in which it fits. The loss of context is always a risk. (Lupa, 2015c).

Other risks involved with fact-checking can be using inaccurate or outdated data, appearing to be biased towards a 
particular political view, or lacking transparency. Lupa claims it does not support or have ties to any political party or syndicate. It also claims to check government and its opposition consistently on federal, state and municipal levels (Lupa, 2015a).

In April 2017, Lupa expanded its actions beyond factchecking and created an educational branch called LupaEducação (LupaEducation). LupaEducação is a training and qualification program in fact-checking techniques for students and professionals from any field of knowledge. According to the agency's website, there were more than three thousand students enrolled in the program in its first year (Lupa, 2015d).

\section{Dealing with misinformation and false information in fact-checking}

Between January $1^{\text {st }}$ and $31^{\text {st }}, 2019$ (our analysis period) Aos Fatos and Agência Lupa published a total of 113 checked articles (50 from Aos Fatos, 63 from Agência Lupa). After carefully reading all these texts, we noticed how their coverage prioritized two fundamental aspects of fact-checking: verifying the information in political speeches and the information circulating on social networks. However, there is a greater tendency to verify information coming from social networks. $78.8 \%$ of all the published articles we analyzed for our study fall into this category. 
Figure 8 - Fact-checks performed by Aos Fatos and Lupa between January $1^{\text {st }}$ and $31^{\text {st }}, 2019$.

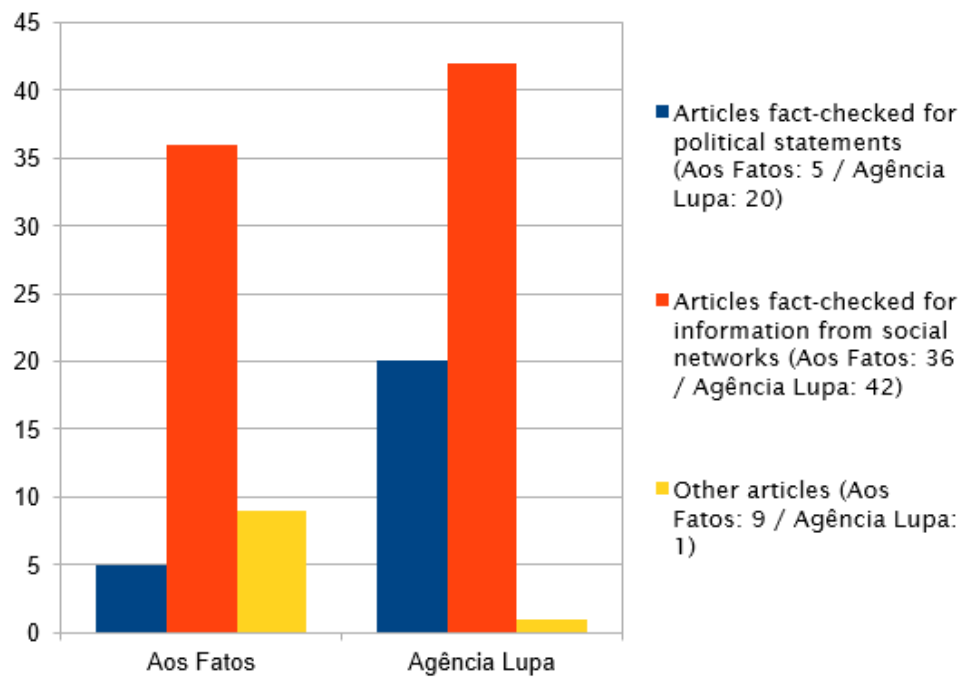

Source: prepared by authors.

Both agencies state that the information, data and images they select for verification comes from material sent by readers. Posts that are labelled as negative are not removed from the social network, as per the partnership agreement with Facebook, but their organic distribution is significantly reduced. Webpages and profiles identified by checking agencies to repeatedly disseminate false information are not able to boost content through paid advertising on Facebook, and thus, the reach of their publications is narrowed. Aos Fatos and Agência Lupa affirm that this kind of action is not focused on censorship but rather combating the viralization of fake news online ${ }^{9}$.

Both agencies do not leave the false content in the body of their texts; they instead include hyperlinks in their articles. In some cases, they include print screens of websites which published the false information. In addition, the same labels that are applied to fact-checking political statements are also applied to information contained on social networks.

In terms of the consistency of the criterion for the 'triangulation of truth', as proposed by Amazeen (2015), 100\% of the information checked by both agencies had the same 
classification and similar labeling regarding the level of veracity for said information which, in a certain way, points to a unified methodological guideline.

Looking at data sources, we also noted that the agency articles written on political statements tend to use official sources and studies to carry out their checks (100\% of the articles use some official source). Regarding the statements themselves, $70 \%$ of them checked by Agência Lupa used official sources to investigate them. This percentage reaches almost $53 \%$ for Aos Fatos.

Butler and Uscinski (2013) criticized the lack of explicit criteria when selecting what is to be checked, and the lack of any real explanation behind the framing used in the checking materials. These agencies do not adhere to the most sophisticated scientific selection criteria, but they do base their productions on relevant subjects in the political and journalistic agendas. This is why the issues with the highest number of information checks were those of government actions and the Brumadinho dam disaster. These two topics together were the subject of 88 checked articles, $77.8 \%$ of the articles published in January.

In terms of checking political statements, Agência Lupa provided wider coverage during our research analysis period, checking statements by different agents from the Executive and Legislative branches at different levels of power, which lends more credibility to the checking results due to the wide range of political persuasions analyzed (Graves \& Glaisyer, 2012), as confirmed by the political affiliations of the subjects which were checked. Aos Fatos' coverage was restricted to President Jair Bolsonaro (PSL) and Senator Flávio Bolsonaro (PSL), which at first, has an opposite impact on the public. 
Table 1 - Distribution of subjects checked in Agência Lupa's coverage between January $1^{\text {st }}$ and $31^{\text {st }}, 2019$.

\begin{tabular}{|l|c|}
\hline \multicolumn{1}{|c|}{ Subject Checked } & $\begin{array}{c}\text { Number of materials } \\
\text { on subject }\end{array}$ \\
\hline Jair Bolsonaro (PSL) - President of Brazil & 03 \\
\hline João Dória (PSDB) - Governor of São Paulo state & 03 \\
\hline Wilson Witzel (PSC) - Governor of Rio de Janeiro state & 03 \\
\hline $\begin{array}{l}\text { Augusto Heleno (PRP) - Chief Minister of the } \\
\text { Institutional Security Cabinet }\end{array}$ & 01 \\
\hline Bruno Covas (PSDB) - Mayor of São Paulo & 01 \\
\hline Camilo Santana (PT) - Governor of Ceará state & 01 \\
\hline $\begin{array}{l}\text { Ciro Comes (PDT) - Former Finance Minister and } \\
\text { former Minister of National Integration }\end{array}$ & 01 \\
\hline $\begin{array}{l}\text { Damares Alves (no party) - Minister of Women, } \\
\text { Family and Human Rights }\end{array}$ & 01 \\
\hline Flávio Bolsonaro (PSL) - Rio de Janeiro Senator & 01 \\
\hline Hamilton Mourão (PRTB) - Vice-president of Brazil & 01 \\
\hline lbaneis Rocha (MDB) - District Governor & 01 \\
\hline $\begin{array}{l}\text { Marcelo Crivela (Republicanos) - Mayor of Rio de } \\
\text { Janeiro }\end{array}$ & 01 \\
\hline Michel Temer (MDB) - Former president of Brazil & 01 \\
\hline Onix Lorenzoni (DEM) - Chief of Staff & 01 \\
\hline $\begin{array}{l}\text { Sérgio Moro (sem partido) - Minister of Justice and } \\
\text { Public Safety }\end{array}$ & 01 \\
\hline Source Prepared bv authors. & 01 \\
\hline
\end{tabular}

Source: prepared by authors.

Table 2 - Distribution of subjects checked in Aos Fatos' coverage between January 1st and 31 st, 2019.

\begin{tabular}{|l|c|}
\hline \multicolumn{1}{|c|}{ Subject Checked } & $\begin{array}{c}\text { Number of materials } \\
\text { on subject }\end{array}$ \\
\hline Jair Bolsonaro (PSL) - President of Brazil & 04 \\
\hline Flávio Bolsonaro (PSL) - Rio de Janeiro Senator & 01 \\
\hline
\end{tabular}

Source: prepared by authors.

In addition to these findings, the nature of the relationship between the checking agencies and those whose statements are checked is also important to our analysis. Despite the obvious intention behind checking political statements, which is to force accountability (Amazeen, 2015), this actually rarely happens. In January 2019, none of the politicians whose statements were checked by the Aos Fatos 
agency responded when questioned about said statements. Agência Lupa asked political agents to explain a total of 69 statements which were either considered to be false, exaggerated or questionable, but they only responded to 18 of them. In terms of percentages, this relates to a $26 \%$ accountability rate. There are also doubts as to how effective this accountability is since none of the explanations which were given was consistent enough to change the label it had been given after fact-checking ${ }^{10}$.

In these responses sent to the checking agencies, we observed a tendency to understand factual errors as technicalities that do not deconstruct or invalidate the main argumentative line of the discourse. This strategy is quite evident in the article Erros e acertos de Damares Alves e Augusto Heleno' ${ }^{11}$ (Errors and successes of Damares Alves and Augusto Heleno) published on January $9^{\text {th }}$, 2019. In regards to the declaration made by Augusto Heleno, labelled as exaggerated, "The number of victims [from automobiles] is almost equal to the number of victims from firearms", the minister's adviser said that the general was just trying to establish an 'order of magnitude' between the two. His answer ignores the fact, highlighted in the fact-check, that the number of deaths by firearms in Brazil was $32.5 \%$ higher than the number of deaths registered in traffic accidents in 2016. This same minister made another statement: "[Brazil has] 2 thousand unfinished construction projects"; this was an underestimated figure, according to Lupa's research. This answer minimizes the error and informs that the data was an approximation, since the intent was to show the effort the government would supposedly have to make to complete all the unfinished projects.

Responses given in other cases seem to give the impression that the statements labeled as problematic were made in a larger context, one ignored by the investigation, sometimes even seeking to offer alternative interpretations for the statements made.

In a statement given by João Dória, labelled as exaggerated, "O Poupatempo" (...) has become a national reference and is being carried out by public servants"13, the calculation by Agência Lupa challenges the governor, showing that 52.3\% of Poupatempo's employees are outsourced, but according to João Dória's interpretation, "every outsourcer in the program provides a public service, that is, they directly serve the population, regardless of the nature of their jobs". Similarly, Wilson Witzel's staff responded to the checkers about the statement: "In 2018, there were more than 600 
homicides [in the first 20 days of government]; in 2017, too". This statement was made on the governor's Twitter account. The agency claims it is not an exaggeration as the governor did not intend to refer only to the number of homicides, but to the total number of deaths in the months of January.

\section{Considerations}

The two basic findings from this article are that fact-checking platforms rely mainly on data provided by official sources and studies from public institutions. We also realized that the analyzed vehicles are not looking to stray too far from the classic ideology of journalism. The dependence on data and studies produced by public and governmental institutions is not necessarily a sign of any investigative deficiency in journalism since, in Brazil, the state is the main collector, organizer and supplier of societal data. It is counterproductive to demand independence in relation to this type of access and data verification method, as quite often these are the only ones available to validate or contest certain information.

We are also able to identify that using official and government data to critique statements made by political agents is not to be repudiated. Even if the state is fulfilling its duty to provide open data, the agents may be more concerned in establishing and strengthening narratives that favor them politically - even if those narratives go against the reality presented in the data, a factor that can cause, and enhance, the silencing and relativization of empirically-observed truths.

Even so, fact-checking vehicles do not just apply their institutional values to seminal aspects of journalistic ideology (objectivity, neutrality and impartiality), they also seek to differentiate themselves by being more transparent in terms of their verification procedures (Poynter, 2016; Amazeen, 2015); using official and government data as their only source for validating checks could damage their credibility. There are cases where the only available data are those produced and organized by the state, and in such cases, we believe this must be emphasized in the fact-checking. Ways around these barriers experienced by checking vehicles could be discovered in other fields. Factchecking is not the only form of verification which has been used 
in the current scenario of transformation in the journalistic field; data journalism is another. Fact-checking professionals can use programming techniques, big data, and social networks to create their own databases, even including or starting with data provided by official sources. This will then allow them to complement and expand the contextual spectrum of fact-checking.

The lack of dialogue between agencies and fact-checkers requires a more in-depth discussion, which is not possible in this article. But we do have a few perspectives that could assist future analyses.

Studies present inconclusive and differing evidence on the effectiveness of fact-checking in relation to democratic improvements (Graves, 2013; Uscinski \& Butler, 2013; Nyhan \& Reifler, 2014; Amazeen, 2015; Dourado, 2016). Although journalistic involvement in factual disputes can help citizens make more empirically-based decisions, there are doubts as to how effective fact-checking is at combating the spread of fake news and misinformation in general. In addition to the problem of selective exposure (lyengar et al., 2008; lyengar \& Hahn, 2009; Lazer et al., 2018), corrections and notes made by fact-checking agencies may be ineffective, or even considered biased, among those who feel their political and ideological positions are being challenged (Nyahan \& Reifler, 2010; Lazer et al., 2018).

The concern with checking information in statements made by public agents can also cause a behavioral change in the subject being checked, as there are possible risks related to said subject's reputation. Still, it is necessary to remember that accountability refers directly to the accountability of the public agent. Regarding the accountability promoted by journalism, we do stress that the function of the press is not to replace institutions that promote government transparency, but it does have a fundamental role in making the actions of government officials public and accessible. "Journalism gives visibility to several actors who may contradict an official statement, joining efforts to amplify the accountability process" (Maia, 2006, p.17).

In that regard, the goal of fact-checking is to be an instrument capable of monitoring authorities. However, in our corpus, we found that agents in the political field are seldom willing to provide clarifications to fact-checks. And even when explanations are given, political actors use them to reinforce their own narratives and minimize factual errors. 
In this way, we can see that silencing fact-checkers is disruptive to the accountability process as the lack of accurate information given in statements is not clarified. Thus, we agree with Dourado's conclusion (2016):

On one hand, journalism can act as a bridge towards accountability, yet this dynamic is more complex and depends more on the seriousness of the social fact than on the work of fact-checking. Labeling a political actor's statement as false can destroy his or her credibility with voters; those statements can be used against them by opponents or peers, or can provoke a debate over a controversial political event. This does not mean, however, that the political agent will incur any sanctions just for having his statement deconstructed. (Dourado, 2016, p.18).

But, what about those who have been fact-checked and remain 'silent'? How do we go about understanding this silence? Orlandi (1997) believes the answers could be complex. He believes that language stabilizes meaning. Conversely, "meaning and subject move freely" within silence (p.27), it references the unexpected and the extent of possible interpretations. "[...] silence is an important matter for excellence, a significant continuum. The real meaning is silence" (p.27). And when the discourse is the object of discussion, "silence is the real discourse" (p.29). In this perspective, discourse (as well as rhetoric) has the ability to 'mold' language, to ideologically 'manipulate' it. Silence, on the other hand, remains in its raw, unwavering state, in all its original potency.

From a certain point of view, when studying signs there is an overlap between language (verbal and non-verbal) and meaning. (...) This overlap meant these two notions blended together, resulting in a situation in which any significant matter speaks, that is, it is given a language (especially verbal) and therefore given meaning. (...) In this same vein, the "empire of the verbal" is placed in our social forms: silence is translated into words. Thus, silence is seen as a language and its specificity is lost, as a significant matter distinct from language. (Orlandi, 1997, p.30).

While trying to establish possible guidelines for an empirical analysis of silence (something which is of great interest to us to further our studies) Orlandi (1997) proposes a possible categorization of silence, listing some 'visible' silences. There are multiple silences. The silence of emotions, of mysticism, of contemplation and introspection, of revolt, resistance, discipline, of defeating the will, of exercising power, etc. When we find that 
the work carried out by the checking agencies focuses mainly on politics and the discourse surrounding it, the silence of the 'exercise of power' draws our attention. "Saying and silencing go hand in hand. (...) There is, therefore, a declination of meaning that results in silencing not as a form for keeping quiet but as a form of saying 'one thing', so as not to say 'another'. In other words, silence cuts through the words. This is its political dimension" (Orlandi, 1997, p. 53). A starting point for future studies.

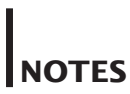

1 Available at: newsroom.fb.com/news/2018/05/hard-questionsfalse-news/. Founded in 2015, the IFCN joins together international fact-checking platforms.

2 Cambridge Analytica was a private company that combined strategic communications with mining and data analysis. In the first half of 2018 , data from 87 million Facebook users were leaked to Cambridge Analytica which then released politically-biased advertisements during the 2016 U.S. presidential campaign. Available at: gl.globo. com/economia/tecnologia/noticia/mark-zuckerberg-depoe-aosenado-sobre-uso-de-dados-pelo-facebook.ghtml

3 Horse-race journalism is an American term for political journalism of elections which focuses on polling data and public perception.

4 Available at: aosfatos.org/checagem-de-fatos-ou-fact-checking/

5 Available at: apublica.org/2018/12/mudancas-na-agencia-publica/

6 Encyclopedia Britannica definition: www.britannica.com/topic/ ad-watch

7 Available at: piaui.folha.uol.com.br/lupa/2015/10/15/de-ondevem-o-fact-checking/

8 Application and platform for chatting on Facebook.

9 Available at: piaui.folha.uol.com.br/lupa/2018/05/10/verificacao -de-noticias-lupa-facebook/ and aosfatos.org/noticias/aos-fatosadere-iniciativa-de-verificacao-de-noticias-do-facebook/ 
10 The statement "[São Paulo has] a higher GDP than that of Argentina, Chile, Colombia, Peru, just to name a few examples", made by João Dória, had its classification label changed from exaggerated to true on January 11, 2019. The label change did not occur because of any response from João Dória to Agência Lupa; the agency had used the wrong methodology to compare the different Gross Domestic Products. Available at: piaui.folha. uol.com.br/lupa/2019/01/11/doria-sp-entrevistas/

Similarly, the statement "Of the 100 best public schools in Brazil, 82 are located in Ceará" had its label changed from false to true. This change occurred after the agency changed its interpretation of the rating system provided by the Basic Education Development Index (Ideb). Available at: piaui.folha.uol. com.br/lupa/2019/01/21/camilo-santana-ceara/

11 Available at: piaui.folha.uol.com.br/lupa/2019/01/09/damaresalves-augusto-heleno/

12 Poupatempo is a São Paulo State Government program implemented in 1997 to facilitate the public's access to public information and services.

13 Available at: piaui.folha.uol.com.br/lupa/2019/01/05/doria-pos se-governador/

\section{REFERENCES}

Amazeen, M. (2015). Revisiting the Epistemology of Fact-Checking. Critical Review: A journal of politics and society, 27(1), 1-22. DOI 10.1080/08913811.2014.99390

Anderson, C. W., BELL, E., \& Shiry, C. (2013). Jornalismo pós-industrial: Adaptação aos novos tempos. Tradução Ada Félix. Revista ESPM, 2(5), 30-89.

Aos Fatos. (2018a, n.d.). O que é checagem de fatos - ou factchecking? Aos fatos. Retrieved from aosfatos.org/checagem-de-fa tos-ou-fact-checking

Aos Fatos. (2018b, n.d.). Nosso método. Aos Fatos. Retrieved from aosfatos.org/nosso-método

Charron, J., \& De Bonvile, J. (2016). Natureza e transformação do jornalismo. Brasília: Editora Insular.

Diniz, A. (2018). Fact-checking no Ecossistema Jornalístico Digital: 
práticas, possibilidades e legitimação. Mediapolis, n. 5, 23-37. DOI: 10.14195/2183-6019_5_2

Dobbs, M. (2012). The rise of political fact-checking: How Reagan inspired a journalistic movement: a reporter's eye view. New America Foundation. Retrieved from www.issuelab.org/resource/the-rise-ofpolitical-fact-checking-how-reagan-inspired-a-journalistic-movementa-reporter-s-eye-view.html

Dourado, T. (2016). Fact-checking como possibilidade de accountability do jornalismo sobre o discurso político: as três iniciativas brasileiras. Proceedings of the $40^{\circ}$ Encontro Anual da Anpocs. Retrieved from www. anpocs.com/index.php/papers-40-encontro/st-10/st17-8/10319-factchecking-como-possibilidade-de-accountability-do-jornalismo-sobre-odiscurso-politico-as-tres-iniciativas-brasileiras/file

Gil, A. C. (1999). Métodos e técnicas de pesquisa social (5 $5^{\text {th }}$ ed.). São Paulo: Atlas.

Graves, L., Nyhan, B., \& Reifler, J. (2015). The diffusion of factchecking - Understanding the growth of a journalistic innovation. American Press Institute. Retrieved from www.issuelab.org/resource/ the-diffusion-of-fact-checking-understanding-the-growth-of-ajournalistic-innovation.html

Graves, L., \& Glaisyer T. (2012). The Fact-Checking Universe in Spring 2012. New America Foundation Media Policy Initiative Research Paper, Retrieved from http://newamerica.net/publications/policy/ the_fact_checking_universe_in_spring_2

Graves, L. (2013). Deciding What's true: Fact-checking journalism and the new ecology of news (doctoral dissertation, Columbia University). Columbia Academic Commons. DOI: 10.7916/D8XG9Z7C

Graves, L. (2016). Boundaries not drawn - mapping the institutional roots of the global fact-checking movement. Journalism Studies, online first, 613-631. DOI: 10.1080/1461670X.2016.1196602.2016

lyengar, S., \& Hahn, K. (2009). Red Media, Blue Media: Evidence of ideological selectivity in media use. Journal of Communication 59(1), 19-29. DOI: 10.1111/j.1460-2466.2008.01402.x

lyengar, S., Hahn, K.S., Krosnick, J.A., \& Walker, J. (2008). Selective exposure to campaign communication: the rue of anticipated agreement and issue public membership. Journal of Politics, 70(1), 186-200. DOI: 10.1017/S0022381607080139

Lazer, D.M.J., Baum, M.A., Benkler, Y., Berinsky, A.J, Greenhill, K.M., Menczer, F., Metzger, M.J, Nyhan, B., Pennycook, G., Rothschild, D., Schudson, M., Sloman, S.A., Sunstein, C.R., Thorson, E.A., Watts, D.J., \& Zittrain, J.L. (2018). The science of fake news: Addressing fake news requires a multidisciplinary effort. Science, 359(6380), 1094- 
1096. DOI: $10.1126 /$ science.aao2998

Lupa. (2015a, Oct 15). Mas de onde vem o fact-checking? Agência Lupa. Retrieved from https://piaui.folha.uol.com.br/lupa/2015/10/15/deonde-vem-o-fact-checking

Lupa. (2015b, Oct. 15). Como a Lupa faz suas checagens?Agência Lupa. Retrieved from https://piaui.folha.uol.com.br/lupa/2015/10/15/ como-fazemos-nossas-checagens/

Lupa. (2015c, Oct. 15). Quais são os riscos e os mitos em torno do fact-checking. Agência Lupa. Retrieved from http://piaui.folha.uol. com.br/lupa/2015/10/15/os-riscos-do-fact-checking

Lupa. (2015d, Oct. 15). O que é a Agência Lupa? Agência Lupa. Retrieved from https://piaui.folha.uol.com.br/lupa/2015/10/15/ como-selecionamos-as-frases-que-serao-checadas

Maia, R. (2006). Mídia e diferentes dimensões da Accountability. E-compós, vol.7, 1-27. DOl: 10.30962/ec.113

Nalon, T. (2016, Sep. 15). Aos Fatos assina compromisso internacional por conduta transparente. Aos Fatos. Retrieved from aosfatos.org/ noticias/aos-fatos-assina-compromisso-internacional-pela-condutatransparente-de-checadores/

Neiser, F. (2015). Fact-checking e o controle da propaganda eleitoral. Revista Ballot, 1(2), 178-212. DOI: 10.12957/ballot.2015.22133

Nyhan, B., \& Reifler, J. (2010). When Corrections fail: the persistence of political misperceptions. Political Behavior, 32(2), 303-330. DOI: 10.1007/s $11109-010-9112-2$

Nyhan, B., \& Reifler, J. (2014). The effect of fact-checking on elites: a field experiment on U.S. State Legislators. American Journal of Political Science, 59(3), 626-640. DOI: 10.1111/ajps.12162

Orlandi, E. (1997). As formas do silêncio no movimento dos sentidos (4 ${ }^{\text {th }}$ ed.). Campinas (SP): Editora da Unicamp.

Poynter. (2016). The commitments of the code of principles. Poynter Institute. Retrieved from https://ifcncodeofprinciples.poynter.org/ know-more/the-commitments-of-the-code-of-principles

Resende, L. (2017, Dec. 23). 'Fake news': usar ou não usar esta expressão? Agência Lupa. Retrieved from piaui.folha.uol.com.br/ lupa/2017/12/23/fake-news-dizer-ou-nao-dizer/

Traquina, N. (2014). Teorias do Jornalismo, Volume 1 - porque as notícias são como são. Florianópolis: Editora Insular.

Uscinski, J., \& Butler, R.W. (2013). The (naïve) epistemology of fact- 
checking. Critical Review: A journal of politics and society, 25(2), 162-180. DOI: 10.1080/089113811.2013.843872.

Yin, R.K. (2001). Estudo de caso: planejamento e métodos (2 ${ }^{\text {nd }}$ ed.). Porto Alegre: Bookman.

DANIEL DE REZENDE DAMASCENO. Master's student in Communication and Contemporary Cultures at Federal University of Bahia (UFBA) and B.A. in Journalism at Federal University of Ceará (UFC). Member of the Discourse and Media Analysis Research Group (CEPAD). Research interests: political journalism, data journalism, fact-checking and fake news. E-mail: danielrezende1@live.com

EDGARD PATRÍCIO. Journalist, professor of the Journalism Course and the Postgraduate Program in Communication at the Federal University of Ceará. He has developed research on the transformations in Journalism, from the categories of work and identity, including the initiatives of independent journalism. He published 'Territoriality and ethos in independent journalism initiatives in Northeast Brazil' [in portuguese: “Territorialidade e ethos em iniciativas de jornalismo independente do Nordeste do Brasil"] (Revista Brasileira de Gestão e Desenvolvimento Regional (G\&DR), 15(4), 183195) E-mail: edgard@ufc.br 